\title{
IS Outsourcing Decision: A Quantitative Approach
}

\author{
Saeed Tajdini (Corresponding author) \\ Faculty of Management, University of Tehran, Tehran, Iran \\ Tel: 98-912-469-0755 E-mail: S.tajdini@ut.ac.ir \\ Mohsen Nazari \\ Faculty of Management, University of Tehran, Tehran, Iran \\ Tel: 98-216-111-7652 E-mail: Mohsen.nazari@ut.ac.ir
}

Received: September 6, 2011

Accepted: October 24, $2011 \quad$ Published: January 16, 2012

doi:10.5539/ijbm.v7n2p113

URL: http://dx.doi.org/10.5539/ijbm.v7n2p113

\begin{abstract}
In the modern hyper competition, the outsourcing decision can be a matter of survival or failure. In this paper, the authors aim at providing an easily adaptable, statistically robust decision model to help firms with deciding whether or not to outsource their IS functions.

Initially, the authors used Factor Analysis to identify the decision criteria. Then, they designed an AHP decision model based on these criteria. The methodology is unique and this methodological combination has never been used before. Results showed that geo-political issue is the most important criterion, followed by strategic, economic and technical considerations. Scholars can take advantage of this to shape their researches or test the results in different contexts. Additionally, the model can be of great help to professionals considering IS outsourcing.
\end{abstract}

Keywords: Information systems outsourcing, AHP, Outsourcing decision factors, Iran

\section{Introduction}

Outsourcing is such an important issue that the father of modern management, Peter Drucker, used to say "Do what you do best and outsource the rest". Of course, researchers have not yet agreed upon a unique definition for outsourcing. The fifth edition of Oxford dictionary of business and management defines outsourcing as "The buying in of components, sub-assemblies, finished products and services from outside suppliers rather than by supplying them internally." De Looff (1997) defined IS outsourcing as "the commissioning of some parts or all of the information system activities of an organization, or transferring the associated human and other IS resources to one or more external supplier". Based on a broad interpretation of outsourcing, it can be defined just as a reliance on external resources (Mol, 2007). Unlike the definition, what seems consistent and shared among different available definitions is that outsourcing is a process in which a function that used to be held in-house is contracted out to be done by external parties. Insourcing is a term that stands apposite to outsourcing. Insourcing is defined as "a common approach using the professional expertise within an organization to develop and maintain the organizations information technology systems" (Baltzan et al., 2009, p. 252).

Outsourcing has been classified in a few ways. In one classification, based on the distance between the exporter of functions and processes (from now on outsourcer) and importer (from now on outsourcee), and the extent of control the outsourcer can exert on the outsourcee and its activities, outsourcing can be categorized into off-shoring, on-shoring and near-shoring. On-shoring refers to a situation in which a company outsources some of its activities to another company within the same country. Near-shoring refers to a situation in which a company outsources some of its activities to another company situated in a nearby country. Off-shoring resembles near-shoring in that the outsourcee is from another country but differs from it in that the outsourcee is in a country far from the outsourcer, commonly without a shared border. As an example of Off-shoring, we can consider Microsoft, IBM, Cisco and Oracle outsourcing their call centers to India. Examples of Near-shoring include US firms outsourcing some of their activities and functions to Mexico or Canada. Businesses being outsourced from China's Beijing to rural areas are examples of On-shoring done to reduce costs by using less demanding workers. Outsourcing is not limited to India or China. Ireland, Canada, India, Philippines and Israel are already among the greatest outsourcees. Brazil, China, Malaysia, Russia, South Africa and Mexico are 
among the greatest up-and-comers in the world.

Hiemstra and Van Tilburg (1993) provide another good classification: capacity and non-capacity outsourcing. Capacity outsourcing refers to a situation where the outsourcer outsources its excess activities due to lack of capacity. But in the latter form, the outsourcer does outsource its activities even if it has free capacity. The aim in the latter form is usually beyond technical affairs and is rooted in strategic considerations.

$30 \%$ of outsourced jobs belong to IT sector, which is a pretty great number with regards to the number of all organizational functions that are subject to outsourcing. Furthermore, almost $60 \%$ of all firms have dealt or are dealing with IT outsourcing while this number is below 10\% in Marketing and Sales function (Baltzan et al, 2009, p.253). As of 2006, outsourcing accounted for jobs worth $\$ 1.2$ trillion per annum. Some economists have predicted that by 2015 , more than 3.3 million U.S. jobs and $\$ 136$ billion worth of wages, will be transferred to developing Asian and African economies, due to cheaper labor markets. Specifically, the IS outsourcing issue is of great importance for developing countries (note 1). In Brazil alone, the number of IT outsourced professionals, functions or activities increased by $127 \%$ in 10 years (Portal Exame, 2006). Moreover, outsourcing- commonly known as over-outsourcing in this specific context is considered as one of the possible causes of economic recessions or its extension. The premise for this conclusion is that a country of outsourcers does not have enough alternative jobs to replace the layoffs. So, outsourcing is not a phenomenon full of blessings and benefits; it may have severe negative effects, too. This adds to the significance of a right outsourcing decision.

Still another aspect that adds to the importance of a sound decision in outsourcing dilemmas is the potential contractual pitfalls. When a company outsources an operation, what it is supposed to manage afterwards is no longer the operations, but the contracts. Contracts become more important than the past operations (Ho et al., 2003).

All the above statistics plus the predicted roaring future of outsourcing due to hyper-competition pressure on developed countries makes outsourcing an issue that needs much more research and clarification. Of course, at the present time a great deal of attention and research has been devoted to the topic but what urges us to conduct this research, is to provide a more coherent and comprehensive model of outsourcing that is able to be put into practice. What we try to add to the current works in this field is a decision model that is handy, accurate and adaptable which has been based on accurate, local data gathered from those who are the real decision makers. We consider two distinct tasks as central to this goal. First, identifying the determinants in outsourcing decisions and detecting the underlying structure in the variables in order to form a concise, rich and educated framework for decision makers. Second, using a quantitative method to arrive at an optimal decision model founded on the findings from the first area. Nevertheless, in almost all the previous studies we examined, researchers had focused only on one part, sometimes basing it on other researchers' findings in other works. This method, we believe, is defective in that outsourcing decision is not global in its characteristics and this phenomenon must be studied on a case-by-case, consistent basis. For example the underlying structure of decision framework in one study might be related to an Asian country while the decision framework built on it by another researcher might be designed for a North-American country. For sure, this model will be defective since the inputs provided may not be relevant to a North-American country. In the current article, we gather the outsourcing determinants from Iranian scholars and top executives, then detect the underlying structure of variables, and finally, provide a model that best suits Iranian firms and firms from other countries with similar characteristics.

The organization of this paper is as follows: in part 2 we provide a review of literature on outsourcing, IS outsourcing and using AHP to assist IS outsourcing decision making. In part 3, we explain our methodology, how the data was gathered, who provided the data and how we arrived at the final output from the initial input. Part 4 is where we explain the process of Factor Analysis we conducted to detect the underlying outsourcing decision factors. In part 5, we describe the modeling stage: how the hierarchy is constructed, weights are calculated and the ultimate decision model is designed. Part 6 shows the results from the AHP modeling: the YES/NO answer we were seeking. In part 7 we explain the results and talk about the implications this research can have for researchers and outsourcing professionals.

\section{Review of Literature}

We organize our review of past literature in two axes. First we review the general issues in outsourcing, i.e. what the benefits, risks and decision factors are. Second, we review some of the major works done with similar methodology and goal.

Though the most tangible, documentable rise of outsourcing as a multi-billion-dollar business may date back to 1954, when General Electric Corp. contracted an outsourcing agreement with Arthur Andersen and Univac (Klepper \& Jones, 1998), we can see that the nature of outsourcing has changed during different eras. As a general statement, outsourcing in the past was a techno-economic issue while today it is more of a strategic one. 
As Rothery and Robertson (1995) explain, outsourcing is not just a costing exercise, but it has a strategic dimension since the firm is trying to adapt to the environment by adjusting its size. Moreover, the target of outsourcing in the past was primarily IT function; however, outsourcing covers both back office and front office activities nowadays. Ketler \& Walstrom (1993) put forward a helpful summary of this changing trend. Table 1 illustrates this summary.

\subsection{Review of Benefits}

All firms are seeking benefits from the smallest through the greatest activities they commit. Whatever such benefits are to the outsourcer, benefits like economic savings, flexibility, and concentration on core-competencies are among the main benefits that come to our minds first. Kremic et al. (2006) summarize the benefits of outsourcing in an informative table. Table 2 illustrates their work.

\subsection{Review of Risks}

Outsourcing, despite the benefits it offers, can be a risky decision. Geo-political issues, currency inconsistency, miscommunications and quality threats are only some of the risks an outsourcer usually faces. Kremic et al. (2006) provided a helpful table summarizing the outsourcing risks as portrayed through different studies by different scholars. Table 3 is an excerpt from their work.

\subsection{Review of Decision models}

Many factors are considered to be the main determinants when making outsourcing decision. Different researchers have emphasized on different factors. Some scholars view technical issues as central to this decision (Rockart et al, 1996). Buck-lew (1992) regards technology, project management, business focus and organization as the main drivers of outsourcing that should be paid much attention when making the outsourcing decision. Yet, some other scholars believe that strategy and strategic issues are of main significance (King, 1994; Quinn \& Hilmer, 1994).

Though researches conducted in the field of outsourcing (mainly identifying the decision factors) are numerous, few studies have seriously tried to devise a quantitative decision model. One study that resembles ours to some extent is that of Yang and Huang (2000). They also try to offer an AHP decision model that can facilitate the decision. They use Management, Technology, Economics, Quality and Strategy as the five factors or criteria in the model. They use this combination of factors to follow a number of former researchers. Our model shares strategic and economical factors with their model and we have mixed Quality and Technology under one factor: technical factor. The extra feature that makes our model more comprehensive is the geo-political factor, which turns out to be far more significant to be negligible. Any model without this criterion is not responsive especially regarding Iran. Moreover, the sub-criteria they use are too few to cover the vast territories of the above criteria and we are not sure that they are the best representatives of their super-ordinate criteria. In our opinion, asking the respondents to do pairwise comparisons using such general, rather abstract factors like strategic and geo-political noticeably reduces the consistency ratio, thus the accuracy of the final model. We believe that the factor loadings that factor analysis provided us with is a scientific and vigorous solution to this problem. This study, though has its own blessings, suffers from a foundational discrepancy between the input data and the output purpose. In other words, those who are going to make the final decision using the provided AHP model had no or little involvement in devising it. This shortcoming is exactly the motive that encouraged us to carry out this research.

Another study that takes advantage of AHP and resembles our study in having two sections was done by Yang et al. (2007). In the first step, they try to prioritize the determinants they found during the review of literature. The factors (criteria) they used are Expectation, Risk, and Environment. Their study is better integrated than that of Yang and Huang (2000) in that they gather their input data first hand. However, the sub-criteria they assign to each criterion are not based on a firm statistical method and seem rather arbitrary. We have tried to level this shortcoming by application of Factor Analysis to extract sub-criteria directly from the associated criteria (in fact, the other way round).

Godwin G. Udo (2000) also utilizes AHP to make a decision model. The criteria used in the model, as the author puts it, are assumed to be the correct criteria used by the targeted decision makers.

Let us mention that though the idea of Benbasat et al. (1987) advocating case studies is fine in its own place, we believe that researches (like Hamzah et al., 2010) that seek to reveal the outsourcing decision mechanism following this methodology will lack generalizability for the most part since results from one case study may be totally different from the results of another study.

\section{Methodology}

\subsection{Participants}

We chose our participants from both academic scholars and top executives. Academic scholars were either 
faculty members or doctoral students of University of Tehran, Tarbiat Modares University and Beheshti University, teaching or majoring in MIS, Management Operations or other fields related to IS outsourcing. The executives who filled the questionnaires were dealing with outsourcing decision either directly or indirectly. Table 4 shows the respondents' profiles. We believe that such a heterogeneous sampling is helpful to add to the reliability of the results and tackle the probable discrepancy between Iranian scholars' and executives' point of view. Initially, a total of 100 participants were given the questionnaires personally or through email. A total of 74 questionnaires were returned. But since the KMO value in Factor analysis turned out to be .41, we had to add to our sample. Therefore, the final number of respondents was increased to 110 from 74 , raising KMO index to .54 .

\subsection{Measure}

In order to gather information about the decision factors as the input for Factor Analysis, questionnaires were handed over to the respondents. The questionnaire is an adapted version of the outsourcing drivers recognized by Ghodeswar and Vaidyanathan (2008). Originally it consisted of 25 items but we added 5 items to localize the questionnaire to cover some factors that we found very relevant to Iran and business conditions in Iran. During factor analysis, 3 items were left out due to low communality value (less than .4). Cronbach's $\alpha$ is .84 , which suggests a high reliability for our adapted questionnaire. The respondents were required to choose how each item contributes to the decision making as a decision factor; how important each factor is in this decision. Each item was evaluated in terms of its importance in a 7-point likert scale from 1 to 7 , where 1 denotes no importance and 7 denotes extreme importance. The questionnaire is available in appendix 1.

In the second part of the study, in order to calculate the local weights of each criterion and sub-criterion, pairwise comparison questionnaires were handed over to the respondent. The questionnaire has a 1-9 likert scale, where 1 denotes equal importance, 3 denotes slight importance, 5 denotes noticeable importance, 7 denotes strong importance and 9 denotes extreme importance of one item over the other. A sample pairwise questionnaire and its responder's guide are present at appendix 2.

\subsection{Procedure}

In this article, our main goal is to provide an AHP decision making model of IS outsourcing, helping firms to better make the outsource vs. in-house production decision. The article can be divided into two distinct parts. The first section deals with identifying factors that are influential in the outsourcing decision. In the second section, using the output from the first section, we try to build the AHP model that can be used to make the decision. To do the first part, we needed to have the decision criteria at hand to skim the decision factors out of them. Subsequently, we gathered experts' opinion on important factors in outsourcing decision making process. After factor analyzing the data, four main factors were detected to have the greatest bearing on the decision making process. In the second section, pairwise comparisons by the same respondents revealed the comparative weight of each factor (criteria) and sub-factors (sub-criteria) in outsourcing decisions. Implementing these weighted factors into an AHP hierarchy, we arrived at the decision model we were after.

\section{Factor Analysis of outsourcing determinants}

When the questionnaires were factor-analyzed in SPSS to detect their underlying structure, a logical pattern revealed. All the 27 variables (after 3 variables were left out) used in the questionnaires grouped into four factors: Economical, geo-political, technical and strategic. The Explanatory factor analysis (EFA) with Varimax rotation method and Principal Component Factoring was used. Initially, 6 factors were detected but we decided to lower the factors by raising the Eigenvalue to 2 since incorporating 6 factors into the AHP model would make it less practical and more complex. The

non-significant Bartlett's test of sphericity rejects the idea that the correlation matrix may be an identity matrix. Also, KMO measure of sampling adequacy was .55, indicating that our sample size is enough. Let us mention that though this value is considered minimum by statistics experts, we could not increase our sample size for the second time without sacrificing the expertise/ knowledge cut-off point we had in mind while choosing our respondents. We had already added to the sample size to increase KMO measure value from .41 to .55 . Undoubtedly, the main reason for the low KMO value was the large number of the variables, comparative to number of cases. We could have decreased the number of questionnaire items; however, this could have cost lowering the questionnaire reliability index. Following Momeni (2007), we believe that .55 for the KMO roughly meets the statistical requirements for a robust Factor Analysis.

The four-factor result makes our model more similar to that of Lacity et al (1996) and dissimilar to that of Ketler and Walstrom (1993). We believe that this four-factor classification is comprehensive enough and takes in the most important factors. The cumulative value for the "Extraction Sums of Squared Loadings" is $68.378 \%$, which we find a very high explanatory power regarding that we are extracting only 4 factors from 27 variables, 
an approximately 1:6 ratio. Table 5 illustrates the most important variables within each factor including their loading on the super-ordinate factor.

\section{Modeling}

The AHP is a general theory of measurement. It is used to derive relative priorities on absolute scales (invariant under the identity transformation) from both discrete and continuous paired comparisons in multilevel hierarchic structures. These comparisons may be taken from actual measurements or from a fundamental scale that reflects the relative strength of preferences and feelings (Saaty, 2006). What makes the AHP a precious tool in decision making is that it utilizes both quantitative and qualitative inputs to choose the best alternative.

\subsection{Levels}

The first level in our model, as usual of AHP models, is the objective: to make an educated decision whether or not to outsource. The criteria based on which we make this decision include economical, geo-political, technical and strategic, which we found to be the main decision factors at earlier stages in our research. Since these criteria are very general, the respondents might have had difficulty associating such abstract criteria to the alternatives. We are not in total agreement with Udo (2000) in this respect, where he proposed that three levels are sufficient. Hence, we decided to include three sub-criteria for each criterion. Following common sense and Saaty's suggestion (1990), these sub-criteria are the variables with the highest loading on the factors they lie beneath. The fourth and final level is where we placed the alternatives. One alternative is outsourcing and the other one is In-house production (not outsourcing).

\subsection{Calculation of Weights}

In order to determine the role that each criterion and its sub-criteria play in the decision making process, we needed to know the weight of each criterion. To do so, as AHP suggests, we asked the respondents to compare each criterion relative to each of the other criteria. Initially, the main criteria were tested against each other. Table 6 shows the resultant pairwise comparison matrix.

In the next stage, respondents repeated the pairwise comparisons for all of the sub-criteria with regards to their peer criteria (under the same super-ordinate criterion). Tables 7 through 10 show the resultant pairwise comparison matrices for the 12 sub-criteria.

As the final stage of weight calculation, we had to find out how each sub-criterion plays a role in the ultimate selection between the two alternatives. To do so in an easy-to-grasp way, we asked our patient respondents to give a 1 to each sub criterion with regards to each alternative if that sub criterion contributes positively to the selection of that alternative. For example, if the respondent felt that the strategic image sub-criterion and consideration to enhance this image should lead the firm NOT to outsource, he would put a 1 for In-house production and a zero for Outsourcing alternative. Then, the average scores $(0$ and 1$)$ were calculated for each sub-criterion. Table 11 shows the results.

\subsection{The AHP Model}

Having constructed the hierarchy and calculated the weights, we could have the graphical representation of the decision process that AHP offers us. Figure 1 shows the AHP model we use for making outsource/not outsource decision.

\section{Results and Discussion}

The global weights for each alternative were what we needed to make the ultimate decision. These weights could be easily calculated. Table 12 and table 13 show the calculation process for global ranks of the two alternatives.

A big advantage that AHP has is that, although plenty of calculations are needed, the final output is reliable, concise and to the point. The sum of global ranks for Outsourcing alternative turned out to be 0.5725 while this value is 0.4257 for In-house production alternative (not outsourcing). To verify the calculations, we used Expert Choice and the results were the same if we disregard some differences in the hundredths and thousandths digits, which must have been due to some digit roundings we did. To be exact, Expert Choice yielded 0.574 and 0.426, respectively. The consistency ratio was only .01, which is far too little to have caused any inaccuracy (Harker, 1989). The low consistency ratio was for the most part due to the meticulous selection of our participants and the well-rounded, highly reliable questionnaire, plus an accompanying responder's guide in addition of oral description of how to fill the pairwise comparison questionnaires when possible.(see appendix 2).

All in all, the results showed that outsourcing of IS function is recommended for Iranian firms. However, the margin between the ranks of the two alternatives was not too large, 0.146 . We believe that due to the political situation and lack of sufficient transportation infrastructure of Iran, respondents were logically concerned with geo-political criteria. Expert Choice sensitivity analysis showed that the more rank of geo-political criterion 
decreases, the more Outsourcing alternative becomes desirable. Figure 2 shows the sensitivity analysis output. Note how distant above the Insourcing alternative does Outsourcing alternative soars when the decisive criterion is the strategic criterion (The left most pillar). On the contrary, note how Outsourcing fades away as a good alternative when the decision is passing through the geo-political filter. The absolute vertical distance between the two alternatives at the decision point is $0.146(0.5725$ minus 0.4257$)$. The wider the distance between the lines when passing a criterion border, the greater impact any change in that criterion will have on the final decision. Following this rule, we can interpret the diagram as follows: geo-political issue is the most sensitive criterion to change. Any minor change in this criterion (relative to change in other criteria) can persuade the decision maker to change his mind. In the second place, strategic criterion is the most sensitive criterion to change. Economical consideration is the third most sensitive criterion to change. Lastly, technical criterion is the least respondent criterion to change. It means that assuming everything else to be constant, raising or lowering the weight of technical criterion significantly (relative to change in other criteria) may not incline the final decision toward Insourcing.

\section{Implications}

Outsourcing scholars have offered different models for outsourcing process. For example, in the view of Chaudhury et al. (1995), outsourcing process model consists of six steps: (1) the company describes whether to outsource or not (2) the company decides on the degree to outsource (3) the company prepares a list of possible vendors and (4) the company start lists vendors based on key decisions (5) company issues request for proposal to receive bids from the short-listed vendors (6) company selects a vendor and develops policies and control to manage outsource issues. To add, Lee and Kim (1997) believe that outsourcing process model involves seven stages: (1) outsourcing strategy selection (2) service provider evaluation (3) service provider selection (4) contract negotiation (5) outsourcing implementation (6) control management and (7) performance feedback. The point is that to follow each one of these approaches, managers need to make up their mind whether or not to outsource first. If this initial decision is made on an erroneous, unilateral, incomprehensive basis, the initiative will fail, regardless of the approach followed later.

Outsourcing decision is not a duty toward which one can shrug off; neither is it something to be done perfunctorily. It involves very high-level strategic decision answering the question 'what to make and what to buy' (Kakouris et al., 2006). According to Ellram et al. (2007), outsourcing has implications for day-to-day management and performance, as well as strategic implications. In order to evaluate the outsourcing decision adequately, the chief information officer (CIO) must spend approximately $80 \%$ of his time, for three to six months (Williamson, 1991).

All said regarding the importance of this vital decision, our methodology is a very flexible and customizable way to make this decision wisely. We encourage other firms and industries to reevaluate the local rankings with regards to their own exclusive conditions. For example, when a Scandinavian firm is planning to outsource its IS function to a country like Sweden, which is politically peaceful, stable and not far away, the model can be adjusted by lowering the geo-political criteria rank, raising the odds of Outsourcing alternative to be selected, assuming everything else to be constant. Executive can take advantage of the sensitivity analysis output (Figure 2) to see how the final decision reacts to each criterion. When considering the necessary and common place trade-offs in managerial decision making, managers should bear in mind the criticality of each criterion in order to remain alert what to seek rigidly and what to let go more comfortably.

As we mentioned earlier in this paper, outsourcing has evolved from a techno-economic phenomenon to a strategic one. As the weights of the criteria and the sensitivity analysis confirm, technical issues are the least important compared to the other three criteria. Seemingly, the transaction cost economics developed by Coase and by Williamson is no more a strong explanatory variable in the outsourcing decision, too. One reason behind this change of importance is the ease of mobility of production factors nowadays. Compare EU of today with the European countries of 100 or even 50 years ago. Then, outsourcing from a Middle Europe country to a Western Europe country or wise-versa might have seemed fine technically. Western Europe had become industrial and the Middle or Eastern Europe couldn't have benefited from their advancements without outsourcing due to many obstacles including weak transportation possibilities, less economic, technological cooperations and so on. But what about today? The single market act of 1987 has made mobility of people, goods, capital, etc possible. Now the movement of a production line can be arranged just within a few minutes. So, technical motive is no longer a strong motive behind outsourcing since technology is no longer a piece of jewel protected in a national safeguard. On the other hand, strategic and economic advantages are great drivers that help many firms survive in the current hyper-competitive world.

In a world where IS owns the biggest share of the total outsourcing and a company's website being down only for a day can cost 3-5 million dollars for the company (Flanagan, 1999), there's no exaggeration when we say a 
wrong outsourcing decision can cost a firm a whole life of reputation and endeavor. So we seriously encourage outsourcing experts to take advantage of this model. The decision model is especially valuable since it has been constructed on first-hand data and gives a final clear-cut solution: to outsource or not. Specifically, Iranian companies can benefit from the results since the questionnaire used in this study was tailored to cover some features very relevant to Iran.

\section{Recommendations for further research}

We recommend other scholars to follow the same methodology in their own countries to see how the selected alternative can change due to changes in the importance of each criterion. Based on the review of literature and our own opinion, technical issues were suspicious of being relatively less important but what turned out to be against our intuitive, initial guesswork was the superior role of geo-political issues. Though this is an important issue, we could not foresee that it can exceed strategic issues in terms of importance. So, the dilemma seems far from solved. Is this importance order exclusive to Iran? What about the order of importance between economical and strategic issues? Can a country like, for example, China stress economical considerations over strategic ones? This was just a sample of possible questions that need further research.

\section{Acknowledgements}

We would like to thank all the respondents who completed the first questionnaire and continued their warm cooperation through the time-taking and prolonged pairwise comparison questionnaires. Employees and executives at Malleable Saipa, Mehrazad co., Kassoun co. and faculty members of university of Tehran, Beheshti University and Tarbiat Modarres University are the ones who helped us significantly.

We also wish to thank Dr. Amir Manian of University of Tehran who helped us devising the questionnaire and provided valuable feedbacks during the course of the research. We are also grateful to Dr. Mansour Momeni of University of Tehran because of his advices about the statistical operations.

\section{References}

Baltzan Paige, Phillips Amy \& Haag Stephen. (2009). Business Driven Technology. McGraw-hill/Irwin.

Benbasat I, Goldstein DK \& Mead M. (1987). The Case Research Strategy in Studies of Information Systems. MIS Q., 11(3): 369-386. http://dx.doi.org/10.2307/248684

Buck-lew M. (1992). To outsource or not. International Journal of Information Management, 12, 3-20. http://dx.doi.org/10.1016/0268-4012(92)90049-V

Chaudhury A., Nam K., \& Rao HR. (1995). Management of information systems outsourcing: a bidding perspective. J. Manage. Info. Syst, 12(2): 131-159.

Coase R. H. (1937). The nature of the firm. Economica, 4: 386-405. http://dx.doi.org/10.1111/j.1468-0335.1937.tb00002.x

De Looff L. (1997). Information systems outsourcing decision-making: a managerial approach. London: Idea Group Publishing

Dong-Hoon Yang, Kim Seongcheol, Nam Changi \& Min Ja-Won. (2007). Developing a decision model for business process outsourcing. Computers \& Operations Research, 34, 3769-3778. http://dx.doi.org/10.1016/j.cor.2006.01.012

Ellram LM, Tate WL \& Billington C. (2007). Services supply management: the next frontier for improved organizational performances, California. Manage. Rev, 49(4): 44-68.

Flanagan, P. (1999). To keep sites performing, expect the unexpected. Business Communications Review, 29: 54-58.

Ghodeswar B., \& Vaidyanathan J. (2008). Business process outsourcing: an approach to gain access to world-class capabilities. Bus. Process. Manage. J., 14(1): 23-38. http://dx.doi.org/10.1108/14637150810849382

Hamzah Noradiva, Aman Aini, Maelah Ruhanita, Md Auzair Sofiah \& Amiruddin Rozita. (2010). Outsourcing decision processes: A case study of a Malaysian firm. African Journal of Business Management, Vol. 4(15): 3307-3314, 4.

Harker PT. (1989). The art and science of decision making: The analytic hierarchy process. The analytic hierarchy process application and studies, Berlin: Springer.

Hiemstra G., \& Van Tilburg JJ. (1993). Inzicht in uitbesteding: ondernemingsstrategie en besturing. Van Gorcum, Assen.

Ho, Violet T., Soon Ang, \& Detmar Straub. (2003). When subordinates become IT contractors: Persistent 
managerial expectations in IT outsourcing. Inform. Systems Res, 14(1) 66-87. http://dx.doi.org/10.1287/isre.14.1.66.14764

Kakouris AP., Polychronopoulos G., \& Binioris S. (2006). Outsourcing decisions and the purchasing process: a system-oriented approach. Mark. Intell Plan, 24(7): 708-729. http://dx.doi.org/10.1108/02634500610711879

Ketler K., \& Walstrom J. (1993). The outsourcing decision, International Journal of Information Management, 13: 449-59. http://dx.doi.org/10.1016/0268-4012 (93)90061-8

King W. R. (1994). Strategic outsourcing decisions. Information Systems Management, 58-61. http://dx.doi.org/10.1080/07399019408964672

Klepper R, \& Jones WO. (1998). Outsourcing Information Technology, Systems, and Services. Upper Saddle River, NJ: Prentice Hall,

Kremic T., Tukel O. I., \& Rom W. O. (2006). Outsourcing decision support: a survey of benefits, risks, and decision factors. Supply Chain Management: An International Journal, Volume 11, Number 6: 467-482. http://dx.doi.org/10.1108/13598540610703864

Lacity M, Willcocks L, \& Feeny D. (1996). The value of selective IT sourcing. Sloan Management Review, 37 (3): $13-25$

Lee JN, \& Kim YG. (1997). Information systems outsourcing strategies for affiliated firms of the Korean conglomerate type. J. Strateg. Info. Syst., 6(3): 203-228.

Mol, M. J. (2007). Outsourcing: Design, process and performance. Cambridge university press. UK.

Momeni M. (2007). Statistical Analysis with SPSS. Ketab-e-no Publications, Tehran, Iran.

Quinn, J. B., \& Hilmer, F. B. (1994). Strategic outsourcing. Sloan Management Review, 35(4): 43-55.

Rockart JF, Earl MJ, \& Ross JW. (1996). Eight imperatives for the new IT organization. Sloan Management Review, 38 (1): 43-55.

Rothery B., \& sRobertson I. (1995). The Truth about Outsourcing. Gower Publishing, Aldershot.

Saaty Thomas L. (1990). Multicriteria Decision Making. Pittsburgh: Rws Pubns publications.

Saaty Thomas L., \& Vargas Luis Gonzalez. (2000). Models, Methods, Concepts \& Applications of the Analytic Hierarchy Process $\left(1^{\text {st }}\right.$ ed.) Springer

Udo GG. (2000). Using analytic hierarchy process to analyze the Information Technology outsourcing decision. Industrial Management and Data systems, 100(9): 421-429. http://dx.doi.org/10.1108/02635570010358348

Williamson M. (1991). The Decision. CIO, 24-35.

Williamson O. (1979). Transaction cost economics: the governance of contractual relations. Journal of Law and Economics, 22(2): 233-61.

Yang Chyan \& Huang Jen-Bor. (2000). A decision model for IS outsourcing. International Journal of Information Management, 20: 225-239. http://dx.doi.org/10.1016/S0268-4012(00)00007-4

Yang Dong-Hoon, Kim Seongcheol, Nam Changi \& Min Ja-Won. (2007). Developing a decision model for business process outsourcing. Computers \& Operations Research, 34: 3769-3778. http://dx.doi.org/10.1016/j.cor.2006.01.012

Note

Note 1. Outsourcing Statistics. Available at http://www.buzzle.com/articles/outsourcing-statistics.html (accessed on January 2011).

Table 1. IS problems and outsourcing form

\begin{tabular}{|l|l|l|}
\hline Time & Problem & The form of outsourcing \\
\hline $1960 \mathrm{~s}$ & Cost of hardware & Facilities or operation management \\
$1970 \mathrm{~s}$ & $\begin{array}{l}\text { Expense of software development } \\
\text { (Lack of IS personnel and high demand } \\
\text { of IS applications) }\end{array}$ & $\begin{array}{l}\text { (In house) } \\
\text { To support vertical integration }\end{array}$ \\
$\begin{array}{l}\text { Early 1990s } \\
\text { Tapid changing and complex technology }\end{array}$ & $\begin{array}{l}\text { On site facilities management and } \\
\text { complete outsourcing } \\
\text { Partial outsourcing }\end{array}$ \\
\hline
\end{tabular}

Source: Ketler K., Walstrom J. (1993).The outsourcing decision, International Journal of Information Management; 13: 449-59. http://dx.doi.org/10.1016/0268-4012 (93)90061-8 
Table 2. Expected outsourcing benefits

\begin{tabular}{|c|c|}
\hline Expected benefits & Referent researches \\
\hline Cost savings & $\begin{array}{l}\text { Adler (2000), Antonucci et al. (1998), Champy (1996), Crone (1992), Drtina } \\
\text { (1994), Dubbs (1992), Fan (2000), } \\
\text { Gordon and Walsh (1997), Hendry (1995), Hubbard (1993), Jennings (2002), } \\
\text { Kakabadse and Kakabadse (2000a), } \\
\text { Kriss (1996), Krizner (2000), Laabs (1993a, b), Laarhoven et al. (2000), } \\
\text { Lankford and Parsa (1999), Large (1999), } \\
\text { LaRock (1993), Lawes (1994), Lee (1994), McCray and Clark (999), Mehling } \\
\text { (1998), Quinn and Hilmer (1994), } \\
\text { Razzaque and Chen (1998), Roberts, V. (2001), Tefft (1998), Tully (1993), } \\
\text { Vining and Globerman (1999), Willcocks } \\
\text { and Currie (1997), Willcocks et al. (1995) }\end{array}$ \\
\hline $\begin{array}{l}\text { Reduced capital } \\
\text { expenditures } \\
\text { Capital infusion } \\
\text { Transfer fixed costs to } \\
\text { variable }\end{array}$ & $\begin{array}{l}\text { Hubbard (1993), Kakabadse and Kakabadse (2000a), Lawes (1994), } \\
\text { McEachern (1996), Muscato (1998), Razzaque and Chen (1998), Tully (1993) } \\
\text { Blumberg (1998), Gordon and Walsh (1997), McEachern (1996) } \\
\text { Blumberg (1998), Kakabadse and Kakabadse (2000a), Kelleher (1990), } \\
\text { Razzaque and Chen (1998) }\end{array}$ \\
\hline Quality improvement & $\begin{array}{l}\text { Blumberg (1998), Campbell (1995), Champy (1996), Hubbard (1993), Jennings } \\
\text { (1997), Jennings (2002), } \\
\text { Kakabadse and Kakabadse (2000a), Kriss (1996), Laabs (1993a, b), Lee (1994), } \\
\text { McEachern (1996), Mehling } \\
\text { (1998), Roberts, V. (2001), Tefft (1998), Willcocks et al. (1995) }\end{array}$ \\
\hline Increased speed & $\begin{array}{l}\text { Drew (1995), Dubbs (1992), Jennings (1997), Kakabadse and Kakabadse } \\
\text { (2000a), Kriss (1996), Krizner (2000), } \\
\text { Quinn and Hilmer (1994), Razzaque and Chen (1998) }\end{array}$ \\
\hline Greater flexibility & $\begin{array}{l}\text { Antonucci et al. (1998), Campbell (1995), Drtina (1994), Gordon and Walsh } \\
\text { (1997), Jennings (1997), Jennings } \\
\text { (2002), Kakabadse and Kakabadse (2000a, b), Muscato (1998), Quinn and } \\
\text { Hilmer (1994), Quinn (1999), Muscato } \\
\text { (1998), Razzaque and Chen (1998), Roberts, V. (2001), Tully (1993), } \\
\text { Willcocks et al. (1995) }\end{array}$ \\
\hline $\begin{array}{l}\text { Access to latest } \\
\text { technology/ }\end{array}$ & $\begin{array}{l}\text { Antonucci et al. (1998), Campbell (1995), Champy (1996), Crone (1992), } \\
\text { Drtina (1994), Gordon and Walsh }\end{array}$ \\
\hline infrastructure & $\begin{array}{l}\text { (1997), Kakabadse and Kakabadse (2000a), Lankford and Parsa (1999), } \\
\text { McEachern (1996), Mehling (1998), } \\
\text { Muscato (1998), Roberts, V. (2001), Wright (2001) }\end{array}$ \\
\hline $\begin{array}{l}\text { Access to skills and } \\
\text { talent }\end{array}$ & $\begin{array}{l}\text { Blumberg (1998), Campbell (1995), Gordon and Walsh (1997), Hill (1994), } \\
\text { Hines and Rich (1998), Jennings } \\
\text { (1997), Lankford and Parsa (1999), Large (1999), Lawes (1994), Mans (1998), } \\
\text { McEachern (1996), Moran (1997), } \\
\text { Muscato (1998), Razzaque and Chen (1998), Richardson (1997), Willcocks et } \\
\text { al. (1995), Wright (2001) }\end{array}$ \\
\hline Augment staff & $\begin{array}{l}\text { Burzawa (1994), Gibson (1993), Gilbert (1999), Jennings (1997), Kakabadse } \\
\text { and Kakabadse (2000a, b), Large } \\
\text { (1999), Lawes (1994), Razzaque and Chen (1998), Richardson (1997), Tefft } \\
\text { (1998), Willcocks et al. (1995), Wright }\end{array}$ \\
\hline
\end{tabular}




\begin{tabular}{|l|l|}
\hline $\begin{array}{l}\text { Increase focus on core } \\
\text { functions }\end{array}$ & $\begin{array}{l}\text { (2001) } \\
\text { Adler (2000), Antonucci (1998), Blumberg (1998), Champy (1996), Crone } \\
\text { (1992), Hubbard (1993), Jennings } \\
\text { (2002), Kakabadse and Kakabadse (2000a, b), Laabs (1993a, b), Lankford and } \\
\text { Parsa (1999), Large (1999), Lawes } \\
\text { (1994), Leavy (1996), McIvor and McHugh (2000), Mehling (1998), Moran } \\
\text { (1997), Quinn and Hilmer (1994), } \\
\text { Roberts, V. (2001), Willcocks et al. (1995), Wolosky (1997), Wright (2001) } \\
\text { McIvor (2000a), Willcocks and Currie (1997), Willcocks (1995) } \\
\begin{array}{l}\text { Get rid of problem } \\
\text { functions }\end{array} \\
\begin{array}{l}\text { Copy competitors } \\
\text { Reduce politic } \\
\text { pressures or scrutiny }\end{array} \\
\begin{array}{l}\text { Willcocks and Currie (1997), Willcocks et al. (1995) } \\
\text { Gegal compliance } \\
\text { Wetter } \\
\text { Willcocks and Currie (1997), }\end{array} \\
\text { ment }\end{array} \quad \begin{array}{l}\text { Willcocks et al. (1995) } \\
\text { Gordon and Walsh (1997), Kakabadse and Kakabadse (2000a) }\end{array}$ \\
\hline
\end{tabular}

Source: Kremic T., Tukel O. I., Rom W. O. (2006). Outsourcing decision support: a survey of benefits, risks, and decision factors, Supply Chain Management: An International Journal, Volume 11, Number 6: 467-482. http://dx.doi.org/10.1108/13598540610703864

Table 3. Potential risks of outsourcing

\begin{tabular}{|c|c|}
\hline Potential risk & References \\
\hline $\begin{array}{l}\text { Unrealized savings or } \\
\text { hidden costs }\end{array}$ & $\begin{array}{l}\text { Alexander and Young (1996), (Journal of Accountancy, 1996), (Works } \\
\text { Management, 1999), Antonucci et al. } \\
\text { (1998), Brown (1997), Dubbs (1992), Earl (1996), Elliot (1995), Hendry } \\
\text { (1995), Jennings (1997), Jones (1993), } \\
\text { Kakabadse and Kakabadse (2000a, b), Lonsdale (1999), McEachern } \\
\text { (1996), Prahalad and Hamel (1990), Quinn } \\
\text { and Hilmer (1994), Willcocks et al. (1995) }\end{array}$ \\
\hline Less flexibility & $\begin{array}{l}\text { Management Accounting (1998), Antonucci et al. (1998), Bryce and } \\
\text { Useem (1998), Gordon and Walsh (1997), } \\
\text { McCray and Clark (1999), Roberts, V. (2001), Tefft (1998), Willcocks and } \\
\text { Currie (1997) }\end{array}$ \\
\hline $\begin{array}{l}\text { Poor contract or poor } \\
\text { selection of partner }\end{array}$ & $\begin{array}{l}\text { Management Accounting (1997, 1998), Crone (1992), Domberger and } \\
\text { Fernandez (1999), Gordon and Walsh } \\
\text { (1997), Hill (1994), Jorgensen (1996), Klopack (2000), Krizner (2000), } \\
\text { Lee and Kim (1999), Mullin (1996), } \\
\text { Willcocks et al. (1995) }\end{array}$ \\
\hline $\begin{array}{l}\text { memory and the difficulty in } \\
\text { reacquiring a } \\
\text { function }\end{array}$ & $\begin{array}{l}\text { Campbell (1995), Earl (1996), Gilbert (1999), Jennings (1997), Kakabadse } \\
\text { and Kakabadse (2000a, b), Kelleher (1990), Leavy (1996), McEachern } \\
\text { (1996), McIvor (2000a), Paoli and Prencipe (1999), Prahalad and Hamel } \\
\text { (1990), Quinn and Hilmer (1994), Quinn (1999), Roberts, V. (2001), } \\
\text { Willcocks and Currie (1997), Willcocks et al. } \\
\text { (1995) }\end{array}$ \\
\hline $\begin{array}{l}\text { Loss of control/core } \\
\text { competence }\end{array}$ & $\begin{array}{l}\text { Anthes (1991), Antonucci et al. (1998), Elliot (1995), Jennings (1997), } \\
\text { Kakabadse and Kakabadse (2000a, b), }\end{array}$ \\
\hline
\end{tabular}




\begin{tabular}{|c|c|}
\hline & $\begin{array}{l}\text { Katz (1995), (Klopack (2000), Leavy (1996), Lonsdale (1999), McEachern } \\
\text { (1996), Ngwenyama and Bryson } \\
\text { (1999), Quinn and Hilmer (1994), Razzaque and Chen (1998), Roberts, V. } \\
\text { (2001) }\end{array}$ \\
\hline Power shift to supplier & $\begin{array}{l}\text { Antonucci et al. (1998), Campbell (1995), Kakabadse and Kakabadse } \\
\text { (2000a), Katz (1995), Lonsdale (1999), } \\
\text { Quinn (1999), Quinn (1999), Roberts, V. (2001), Willcocks and Currie } \\
\text { (1997) }\end{array}$ \\
\hline $\begin{array}{l}\text { Supplier problems (poor } \\
\text { performance or }\end{array}$ & $\begin{array}{l}\text { Avery (2000), Baden-Fuller et al. (2000), Brown (1997), Bryce and Useem } \\
\text { (1998), Earl (1996), Elliot (1995), Iyer }\end{array}$ \\
\hline $\begin{array}{l}\text { bad relations, opportunistic } \\
\text { behavior, not }\end{array}$ & $\begin{array}{l}\text { and Kusnierz (1996), Kakabadse and Kakabadse (2000a), Katz (1995), } \\
\text { Laabs (1998), Lawes (1994), Lonsdale }\end{array}$ \\
\hline $\begin{array}{l}\text { giving access to best talent } \\
\text { or technology) }\end{array}$ & $\begin{array}{l}\text { (1999), Mans (1998), Quinn and Hilmer (1994), Razzaque and Chen } \\
\text { (1998), Roberts, V. (2001), Vining and }\end{array}$ \\
\hline & $\begin{array}{l}\text { Globerman (1999), Willcocks and Currie (1997), Willcocks et al. (1995), } \\
\text { Willis (1996) }\end{array}$ \\
\hline $\begin{array}{l}\text { Losing customers, } \\
\text { opportunities, or } \\
\text { reputation }\end{array}$ & $\begin{array}{l}\text { Blumberg (1998), Brown (1997), Kakabadse and Kakabadse (2000a), } \\
\text { Quinn and Hilmer (1994), Roberts, V. } \\
\text { (2001) }\end{array}$ \\
\hline $\begin{array}{l}\text { Uncertainty/changing } \\
\text { environment }\end{array}$ & $\begin{array}{l}\text { Earl (1996), Gordon and Walsh (1997), Lawes (1994), Lonsdale (1999), } \\
\text { Willcocks and Currie (1997) }\end{array}$ \\
\hline $\begin{array}{l}\text { Poor morale/employee } \\
\text { issues }\end{array}$ & $\begin{array}{l}\text { Blumberg (1998), Gordon and Walsh (1997), Kakabadse and Kakabadse } \\
\text { (2000a), Quinn (1999), Razzaque and }\end{array}$ \\
\hline & Chen (1998), Story (2000) \\
\hline \multicolumn{2}{|l|}{ Other: } \\
\hline Loss of synergy & Campbell (1995), Willcocks and Currie (1997) \\
\hline Create competitor & Klopack (2000) \\
\hline Conflict of interest & Avery (2000), Gordon and Walsh (1997) \\
\hline Security issues & Graham (1996), Peltier (1996) \\
\hline $\begin{array}{l}\text { False sense of } \\
\text { irresponsibility }\end{array}$ & Roberts, P. (2001), Sherter (1997), Widger (1996) \\
\hline Legal obstacles & Gordon and Walsh (1997), Graham (1996) \\
\hline Skill erosion & Lafferty and Roan (2000) \\
\hline
\end{tabular}

Potential risks of outsourcing. Source: Kremic T., Tukel O. I., Rom W. O. (2006). Outsourcing decision support: a survey of benefits, risks, and decision factors, Supply Chain Management: An International Journal, Volume 11, Number 6: 467-482. http://dx.doi.org/10.1108/13598540610703864 
Table 4. Respondents' profiles

\begin{tabular}{|l|l|c|c|}
\hline & & Frequency & Percentage \\
\hline Gender & Male & 101 & 92 \\
\multirow{5}{*}{ Background } & Female & 9 & 8 \\
& Academic scholar & 62 & 57 \\
& Professional & 48 & 43 \\
Education & $30-40$ & 24 & 22 \\
& $40-50$ & 73 & 66 \\
& $>50$ & 13 & 12 \\
& College & 7 & 6.4 \\
Outsourcing experience & Bachelor's & 41 & 37.2 \\
& Master's & 12 & 11 \\
& Doctorate & 50 & 45.4 \\
& 0-5 years & 26 & 23.6 \\
& 5-10 years & 44 & 40 \\
& $10-15$ years & 30 & 27.3 \\
& $>15$ years & 10 & 9.1 \\
\hline
\end{tabular}

Table 5. The four factors, the main variables and their loadings on each factor

\begin{tabular}{|c|c|c|c|}
\hline Factor & Variables name & Variable abbreviation & Loadings \\
\hline \multirow{3}{*}{ 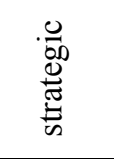 } & To achieve a greater focus on core business. & Core business & .814 \\
\hline & To increase flexibility to deal with ever changing business conditions. & Flexibility & .738 \\
\hline & To improve credibility and image by associating with superior providers. & Image & .835 \\
\hline \multirow{3}{*}{ 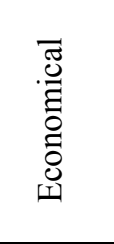 } & To achieve cost reduction with enhanced performance. & Cost reduction & .858 \\
\hline & $\begin{array}{l}\text { To handle varying demand more efficiently because of economies of } \\
\text { scale }\end{array}$ & Economy of scale & .801 \\
\hline & $\begin{array}{l}\text { To achieve aggressive growth objectives by gaining increased market } \\
\text { access. }\end{array}$ & Growth & .808 \\
\hline \multirow{3}{*}{ 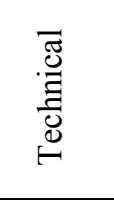 } & To obtain expertise, skills, and innovative ideas. & Skill & .627 \\
\hline & $\begin{array}{l}\text { To improve management and control of operational process including } \\
\text { risk }\end{array}$ & $\begin{array}{l}\text { Management of } \\
\text { Operational Process }\end{array}$ & .830 \\
\hline & To expand capacity to design, test and build new products and service. & New product & .639 \\
\hline \multirow{3}{*}{$\begin{array}{l}: \Xi \\
0 \\
0 \\
0 \\
0 \\
0 \\
0 \\
0\end{array}$} & Long distance between the outsourcer and outsourcee & Distance & .888 \\
\hline & Political sanctions and other intergovernmental barriers & Political issues & .860 \\
\hline & Language barriers in the outsourcee's country & Language barriers & .924 \\
\hline
\end{tabular}

Table 6. The main criteria local weights

\begin{tabular}{|l|c|c|c|c|}
\hline & strategic & Economical & Technical & Geographical \\
\hline strategic & 1 & 2 & 3 & 1.4 \\
Economical & $1 / 2$ & 1 & 1.5 & 1.4 \\
Technical & $1 / 3$ & $1 / 1.5$ & 1 & $1 / 3$ \\
Geographical & $1 / 1.4$ & $1 / 1.4$ & 3 & 1 \\
\hline
\end{tabular}

Table 7. Local weights for the three sub-criteria for strategic criterion

\begin{tabular}{|l|c|c|c|}
\hline & Core business & Flexibility & Image \\
\hline Core business & 1 & 2.9 & 2.7 \\
Flexibility & $1 / 2.9$ & 1 & 1.6 \\
Image & $1 / 2.7$ & $1 / 1.6$ & 1 \\
\hline
\end{tabular}


Table 8. Local weights for the three sub-criteria for economical criterion

\begin{tabular}{|l|c|c|c|}
\hline & Cost reduction & Economy of Scale & Growth \\
\hline Cost reduction & 1 & 1.9 & 3.2 \\
Economy of Scale & $1 / 1.9$ & 1 & 1.7 \\
Growth & $1 / 3.2$ & $1 / 1.7$ & 1 \\
\hline
\end{tabular}

Table 9. Local weights for the three sub-criteria for technical criterion

\begin{tabular}{|l|l|l|l|}
\hline & Skill & $\begin{array}{l}\text { Management of } \\
\text { Operational Process }\end{array}$ & New product \\
\hline Skill & 1 & 1.2 & 2.8 \\
$\begin{array}{l}\text { Management of } \\
\text { Operational Process }\end{array}$ & $1 / 1.2$ & 1 & 2.4 \\
New product & $1 / 2.8$ & $1 / 2.4$ & 1 \\
\hline
\end{tabular}

Table 10. Local weights for the three sub-criteria for geo-political criterion

\begin{tabular}{|l|l|l|l|}
\hline & Distance & Language barriers & Political issues \\
\hline Distance & 1 & 1.3 & 3.3 \\
Language barriers & $1 / 1.3$ & 1 & 2.6 \\
Political issues & $1 / 3.3$ & $1 / 2.6$ & 1 \\
\hline
\end{tabular}

Table 11. The role of each sub-criterion in the ultimate selection between the two alternatives

\begin{tabular}{|c|c|c|c|}
\hline$\cdot \frac{\pi}{0}$ & Sub-criteria & $\begin{array}{l}\% \text { of } 1 \text { s for } \\
\text { outsourcing }\end{array}$ & $\begin{array}{l}\% \text { of } 1 \mathrm{~s} \text { for In-house } \\
\text { production }\end{array}$ \\
\hline \multirow{3}{*}{ 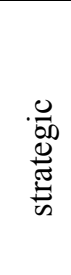 } & To achieve a greater focus on core business. & 92 & 8 \\
\hline & $\begin{array}{l}\text { To increase flexibility to deal with ever changing business } \\
\text { conditions. }\end{array}$ & 86 & 14 \\
\hline & $\begin{array}{l}\text { To improve credibility and image by associating with superior } \\
\text { providers. }\end{array}$ & 69 & 31 \\
\hline \multirow{3}{*}{ 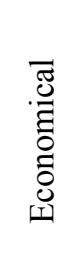 } & To achieve cost reduction with enhanced performance. & 96 & 4 \\
\hline & $\begin{array}{l}\text { To handle varying demand more efficiently because of } \\
\text { economies of scale }\end{array}$ & 44 & 56 \\
\hline & $\begin{array}{l}\text { To achieve aggressive growth objectives by gaining increased } \\
\text { market access. }\end{array}$ & 53 & 47 \\
\hline \multirow{3}{*}{ 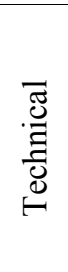 } & To obtain expertise, skills, and innovative ideas. & 88 & 12 \\
\hline & $\begin{array}{l}\text { To improve management and control of operational process } \\
\text { including risk }\end{array}$ & 46 & 54 \\
\hline & $\begin{array}{l}\text { To expand capacity to design, test and build new products and } \\
\text { service. }\end{array}$ & 55 & 45 \\
\hline \multirow{3}{*}{ 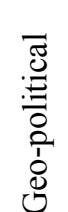 } & Long distance between the outsourcer and outsourcee & 0 & 100 \\
\hline & Political sanctions and other intergovernmental barriers & .07 & 93 \\
\hline & Language barriers in the outsourcee's country & 0 & 100 \\
\hline
\end{tabular}


Table 12. The global ranks for each sub-criterion with regards to Outsourcing alternative

\begin{tabular}{|l|c|c|c|c|}
\hline sub-criterion & $\begin{array}{c}\text { Sub-criterion } \\
\text { local weight }\end{array}$ & $\begin{array}{c}\text { Super-ordinate } \\
\text { criterion local weight }\end{array}$ & $\begin{array}{c}\text { Sub-criterion weight } \\
\text { on Outsourcing } \\
\text { alternatives }\end{array}$ & $\begin{array}{c}\text { Global rank } \\
\text { (multiple of the } \\
\text { previous columns) }\end{array}$ \\
\hline Core business & 0.58 & 0.384 & 0.92 & 0.2049024 \\
Flexibility & 0.239 & 0.384 & 0.86 & 0.07892736 \\
Image & 0.179 & 0.384 & 0.69 & 0.04742784 \\
Cost reduction & 0.521 & 0.217 & 0.96 & 0.10853472 \\
Economy of Scale & 0.296 & 0.217 & 0.44 & 0.02826208 \\
Growth & 0.183 & 0.217 & 0.53 & 0.02104683 \\
Skill & 0.45 & 0.119 & 0.88 & 0.047124 \\
Management of & 0.39 & 0.119 & 0.46 & 0.0213486 \\
Operational & & & 0.55 & 0.010472 \\
Process & 0.16 & 0.119 & 0 & 0 \\
New product & 0.18 & 0.279 & 0.07 & 0.0044919 \\
Distance & 0.23 & 0.279 & 0 & 0.57253773 \\
Language barriers & 0.59 & 0.279 & & \\
Political issues & & & & \\
SUM & & & & \\
\hline
\end{tabular}

Table 13. The global ranks for each sub-criterion with regards to In-house production alternative

\begin{tabular}{|l|l|l|l|l|}
\hline sub-criterion & $\begin{array}{l}\text { Sub-criterion } \\
\text { local weight }\end{array}$ & $\begin{array}{l}\text { Super-ordinate } \\
\text { criterion local weight }\end{array}$ & $\begin{array}{l}\text { Sub-criterion weight on } \\
\text { alternatives }\end{array}$ & $\begin{array}{l}\text { Global rank } \\
\text { (multiple of the } \\
\text { previous columns) }\end{array}$ \\
\hline Core business & 0.58 & 0.384 & 0.08 & 0.0178176 \\
Flexibility & 0.239 & 0.384 & 0.14 & 0.01284864 \\
Image & 0.179 & 0.384 & 0.31 & 0.02130816 \\
Cost reduction & 0.521 & 0.217 & 0.04 & 0.00452228 \\
Economy of Scale & 0.296 & 0.217 & 0.56 & 0.03596992 \\
Growth & 0.183 & 0.217 & 0.47 & 0.01866417 \\
Skill & 0.45 & 0.119 & 0.12 & 0.006426 \\
Management of & 0.39 & 0.119 & 0.54 & 0.0250614 \\
Operational Process & & 0.119 & 0.45 & 0.008568 \\
New product & 0.16 & 0.279 & 1 & 0.05022 \\
Distance & 0.18 & 0.279 & 0.93 & 0.0596781 \\
Language barriers & 0.23 & 0.279 & 1 & 0.16461 \\
Political issues & 0.59 & & & 0.42569427 \\
SUM & & & & \\
\hline
\end{tabular}




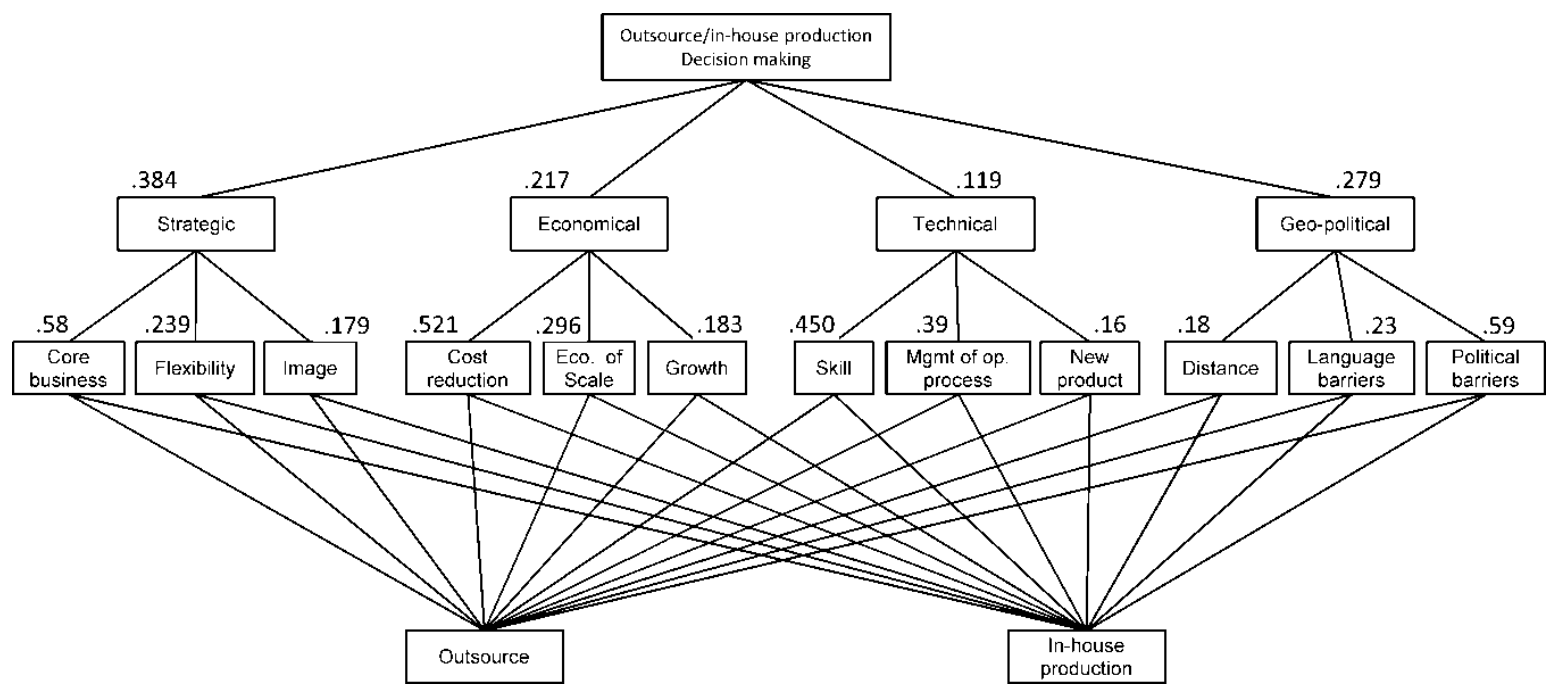

Figure 1. The AHP model for outsourcing decision. Level one is the objective, level two are the criteria, level three are the sub-criteria and level four are the alternatives, to outsource or not outsource. In order to avoid

illegibility, the weights of the sub-criteria in regards to each alternative is not included in the figure

Criticality

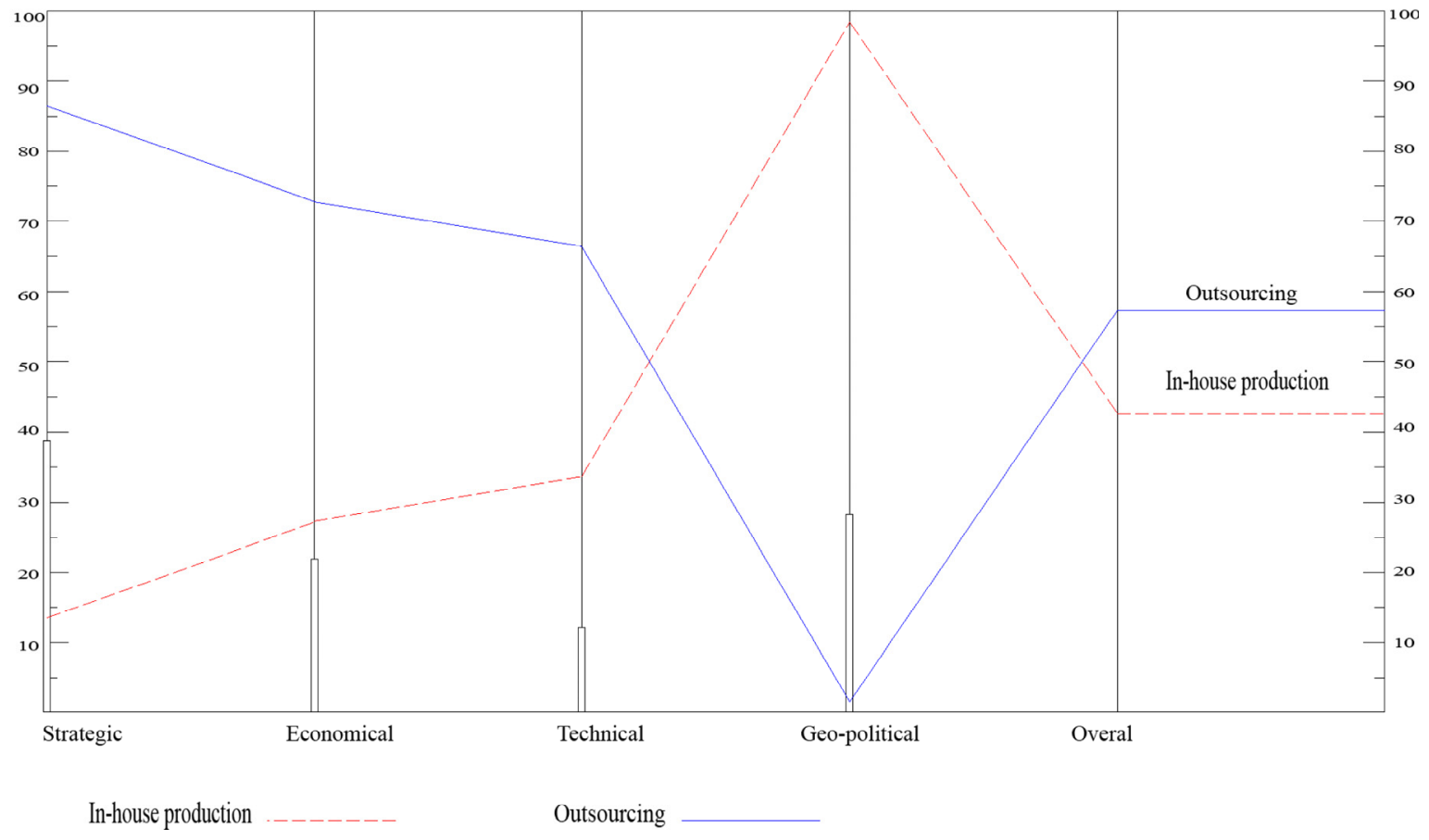

Figure 2. Performance sensitivity analysis by Expert Choice. The four criteria are distributed in the horizontal axis. The continuous line represents Outsourcing alternative and the dotted line represents Insourcing alternative. The position of each line when passing through each criterion shows how critically that criterion contributes to the selection of that specific alternative. 
Appendix 1. The questionnaire used for Factor Analysis

\begin{tabular}{|c|c|c|c|c|c|}
\hline \# & Items & $\begin{array}{c}\text { No } \\
\text { importance } \\
1\end{array}$ & $\begin{array}{c}\text { Important } \\
3\end{array}$ & $\begin{array}{c}\text { Very } \\
\text { important } 5\end{array}$ & $\begin{array}{l}\text { Extremely } \\
\text { important } \\
7\end{array}$ \\
\hline 1 & $\begin{array}{l}\text { Access to products, services and emerging } \\
\text { technologies. }\end{array}$ & & & & \\
\hline 2 & $\begin{array}{l}\text { Expanding its operations into a new } \\
\text { geographical region. }\end{array}$ & & & & \\
\hline 3 & $\begin{array}{l}\text { Greater thrust on market positioning and } \\
\text { new product development. }\end{array}$ & & & & \\
\hline 4 & $\begin{array}{l}\text { Management and control of operational } \\
\text { process including risk management. }\end{array}$ & & & & \\
\hline 5 & $\begin{array}{l}\text { Managing demand efficiently through } \\
\text { outsider's automation, process maturity } \\
\text { and the latest technology. }\end{array}$ & & & & \\
\hline 6 & $\begin{array}{l}\text { Political, economic and social stability of } \\
\text { outsourcee country }\end{array}$ & & & & \\
\hline 7 & $\begin{array}{l}\text { Focusing on enablers of business growth } \\
\text { and strategies to fulfill them }\end{array}$ & & & & \\
\hline 8 & $\begin{array}{l}\text { Obtaining expertise, skills, and innovative } \\
\text { ideas. }\end{array}$ & & & & \\
\hline 9 & $\begin{array}{l}\text { Obtaining technologies which otherwise } \\
\text { will not be available. }\end{array}$ & & & & \\
\hline 10 & $\begin{array}{l}\text { Increasing flexibility to deal with ever } \\
\text { changing business conditions. }\end{array}$ & & & & \\
\hline 11 & $\begin{array}{l}\text { Improving credibility and image by } \\
\text { associating with superior providers. }\end{array}$ & & & & \\
\hline 12 & $\begin{array}{l}\text { Eliminating the fixed cost of internal staff } \\
\text { by moving the function to a supplier. }\end{array}$ & & & & \\
\hline 13 & $\begin{array}{l}\text { Improving operating performance, quality, } \\
\text { timeliness, and productivity. }\end{array}$ & & & & \\
\hline 14 & Reducing investment in assets. & & & & \\
\hline 15 & $\begin{array}{l}\text { Stretching its limit in handling the } \\
\text { increased volume of business. }\end{array}$ & & & & \\
\hline 16 & $\begin{array}{l}\text { Reducing the invested capital funds in } \\
\text { non-core business functions. }\end{array}$ & & & & \\
\hline 17 & $\begin{array}{l}\text { Assigning operational issues to an outside } \\
\text { expert. }\end{array}$ & & & & \\
\hline 18 & $\begin{array}{l}\text { Accessing an outside provider's lower } \\
\text { cost structure. }\end{array}$ & & & & \\
\hline 19 & $\begin{array}{l}\text { Handling varying demand more } \\
\text { efficiently because of economies of scale. }\end{array}$ & & & & \\
\hline 20 & Political barriers like political sanctions & & & & \\
\hline 21 & $\begin{array}{l}\text { Leveraging on the service provider's best } \\
\text { process, capacity and systems. }\end{array}$ & & & & \\
\hline 22 & Reducing or control of operating costs. & & & & \\
\hline
\end{tabular}




\begin{tabular}{|l|l|l|l|l|l|}
\hline 23 & Greater focus on core business. & & & & \\
\hline 24 & $\begin{array}{l}\text { Achieve cost reduction with enhanced } \\
\text { performance. }\end{array}$ & & & & \\
\hline 25 & $\begin{array}{l}\text { Distance between outsourcer and } \\
\text { outsourcee }\end{array}$ & & & & \\
\hline 26 & $\begin{array}{l}\text { To achieve aggressive growth objectives } \\
\text { by gaining increased market access. }\end{array}$ & & & & \\
\hline 27 & $\begin{array}{l}\text { To expand capacity to design, test and } \\
\text { build new products and service. }\end{array}$ & & & & \\
\hline
\end{tabular}

Appendix 2. Pairwise comparison questionnaire for the main criteria

\begin{tabular}{|l|c|l|l|l|}
\hline & strategic & Economical & Technical & geo-political \\
\hline strategic & 1 & & & \\
\hline Economical & & 1 & & \\
\hline Technical & & & 1 & \\
\hline geo-political & & & & 1 \\
\hline
\end{tabular}

Scoring guide

\begin{tabular}{|l|l|}
\hline Scores & Score meaning \\
\hline 1 & The Row and column being compared are of equal importance \\
\hline 3 & The row is slightly more important than the column we compare it to \\
\hline 5 & The row is noticeably more important than the column we compare it to \\
\hline 7 & The row is strongly more important than the column we compare it to \\
\hline 9 & The row is extremely more important than the column we compare it to \\
\hline $1 / 3$ & The column is slightly more important than the row we compare it to \\
\hline $1 / 5$ & The column is noticeably more important than the row we compare it to \\
\hline $1 / 7$ & The column is strongly more important than the row we compare it to \\
\hline $1 / 9$ & The column is extremely more important than the row we compare it to \\
\hline
\end{tabular}

